Info Artikel Diterima Januari 2018

Disetujui Maret 2018

Dipublikasikan April 2018

\title{
ANALISIS KANDUNGAN UNSUR HARA LIMBAH CAIR TEH HIJAU SEBAGAI BAHAN PUPUK ORGANIK PADA BIBIT TEH
}

\author{
Retno Muningsih, Gunawan Ciptadi \\ Politeknik LPP JIn. LPP 1A Balapan Yogyakarta \\ e-mail: retnomuningsih@gmail.com
}

\begin{abstract}
Tea shoots processing intended to alter the chemical composition of fresh tea shoots, so bring the desired properties. Freshly plucked tea leaves containing water $75 \%$ of the weight of the leaves. The water contained in the leaves removed through the process of withering and drying in the processing of green tea. Green tea liquid waste obtained from the milling process and not used optimally, it needs a touch technology that can turn liquid waste into useful liquid organic fertilizer. The use of an activator / starter (micro-organisms) in green tea liquid waste is an alternative technology to improve the health and fertility of the soil and plants. The purpose of this study to determine the benefits of using liquid waste of green tea on the growth of tea seeds. Results of analysis of the utilization liquid waste of green tea with the addition of starter (EM-4) has not shown any real effect on the percentage of seedling growth and seedling growth (plant height, number of leaves and greenery).
\end{abstract}

Keywords: liquid waste, green tea, organic matter.

\section{PENDAHULUAN}

Produksi bersih adalah strategi pengelolaan lingkungan yang sifatnya mengarah pada pencegahan terpadu yang diterapkan pada seluruh siklus produksi. Hal tersebut bertujuan untuk meningkatkan produktivitas melalui efisiensi yang lebih baik pada penggunaan bahan mentah, energi dan air, menjaga kualitas lingkungan melalui pengurangan sumber penghasil limbah atau emisi, serta mereduksi dampak produk terhadap lingkungan. Salah satu kegiatan yang dapat dilakukan dalam mendukung produksi bersih di Industri teh adalah pemanfaatan kembali limbah yang dihasilkan dari proses produksi.

Pengolahan pucuk teh dimaksudkan untuk mengubah komposisi kimia pucuk teh segar sehingga memunculkan sifat-sifat yang dikehendaki. Teh hijau merupakan hasil olahan pucuk teh tanpa proses fermentasi, yaitu dibuat dengan cara menginaktifkan enzim fenolase yang ada dalam pucuk daun teh segar, dengan cara pemanasan sehingga oksidasi terhadap katekin (zat antioksidan) dapat dicegah. Pemanasan dapat dilakukan dengan dua cara yaitu dengan udara kering (pemanggangan/sangrai) dan pemanasan basah dengan uap panas (steam). Pemanggangan daun teh akan memberikan aroma dan flavor yang lebih kuat dibandingkan dengan pemberian uap panas. Keuntungan dengan cara pemberian uap panas, adalah warna teh dan seduhannya akan lebih hijau terang. Di Cina, untuk membuat teh hijau dilakukan pemberian uap panas pada daun teh, sedangkan di Jepang daun tehnya disangrai. Pada kedua metode tersebut, daun teh 
sama-sama menjadi layu, tetapi karena daun teh ini segera dipanaskan setelah pemetikan, maka hasil tehnya tetap berwarna hijau.

Teh hijau banyak digunakan di farmasi dan kesehatan. Daun teh yang baru dipetik mengandung air $75 \%$ dari berat daun dan sisanya berupa padatan dan terdiri dari bahan organik dan anorganik. Bahan organik yang penting dalam pengolahan teh antara lain polifenol, karbohidrat dan turunannya, ikatan nitrogen, pigmen dan enzim-enzim. Air yang terkandung di daun dikeluarkan melaui proses pelayuan dan pengeringan dalam pengolahan teh hijau, sehingga menghasilkan limbah cair.

Pemanfaatan limbah cair teh belum banyak diteliti seperti halnya limbah padat teh. Beberapa literatur menyebutkan bahwa limbah padat industri teh ternyata dapat dimanfaatkan untuk berbagai keperluan antara lain menjadi bahan baku pembuatan papan partikel dan pupuk organik serta absorben pewarna tekstil. Menurut Retnowati (2005), zat warna dalam limbah cair industri tekstil mengandung logam berat, seperti zat warna amaran yang mengandung merkuri, arsenat, timah, serta cadmium dengan konsentrasi satu sampai sepuluh ppm. Hasil penelitian menunjukkan ampas teh dapat digunakan sebagai adsorben larutan amaran dan biru metilen untuk mengganti karbon aktif yang cenderung memakan biaya lebih besar. Hasil penelitian lain yang membanggakan terhadap limbah teh adalah limbah teh hitam dapat menurunkan produksi gas metan hasil fermentasi ternak sapi perah atau sapi potong. Limbah teh tersebut digunakan sebagai bahan campuran makanan ternak. Senyawa tanin di dalam ampas teh hitam mampu menghambat metabolisme dan menurunkan jumlah protozoa diikuti penurunan produksi gas metan namun tidak berpengaruh pada kadar protein mikroba, sehingga dapat meningkatkan produktivitas peternakan.

Penggunaan activator/starter (mikro organisme) pada limbah cair teh hijau merupakan suatu teknologi alternatif untuk meningkatkan kesehatan dan kesuburan tanah dan tanaman. Effective microorganism 4 atau EM 4 merupakan suatu kultur campuran berbagai mikro organism bermanfaat seperti bakteri fotosintesis, bakteri asam laktat, ragi, actinomycetes dan jamur peragian. Bakteri fotosintesis berfungsi 1) membentuk zat-zat asam amino, asam nukleat, zat-zat bioaktif, dan gula bagi sekresi akar tumbuhan, bahan organik dan gas berbahaya dengan menggunakan sinar matahari dan bumi sebagai sumber energi; 2) meningkatkan pertumbuhan mikro organisme lainnya. Bakteri asam laktat berfungsi: 1) menghasilkan asam laktat dan gula; 2) menekan pertumbuhan mikro organisme yang merugikan: 3) meningkatkan percepatan perombakan bahanbahan organik; 4) menghancurkan bahan-bahan organik seperti lignin dan selulosa serta memfermentasikannya tanpa menimbulkan pengaruh-pengaruh merugikan yang diakibatkan oleh bahan-bahan organik yang tidak terurai. Ragi berfungsi : 1) membentuk zat anti bakteri dan bermanfaat bagi pertumbuhan tanaman dari asamasam amino dan gula yang dikeluarkan oleh bakteri fotosintesis. Actinomycetes berfungsi : 1) menghasilkan zat-zat anti mikroba dari asam amino yang dihasilkan oleh bakteri fotosintesis dan bahan organik; 2) menekan pertumbuhan jamur dan bakteri. Fungsi jamur fermentasi/peragian: 1) menguraikan bahan organik secara cepat untuk menghasilkan alkohol, ester dan zat-zat anti mikroba; 2) menghilangkan bau serta mencegah serbuan serangga dan ulat yang merugikan. 
Merujuk pada hasil penelitian limbah padat yang sudah banyak diteliti, tidak menutup kemungkinan bahwa limbah cair hasil pengolahan pucuk teh dapat dimanfaatkan sebagai pupuk cair organik dengan penambahan mikro organisme bermanfaat melalui proses fermentasi. Tujuan penelitian ini adalah untuk mengetahui kandungan unsur hara limbah cair hasil dari pengolahan teh hijau dan fermentasi limbah cair teh hijau yang digunakan sebagai bahan pupuk organik.

\section{BAHAN DAN METODE PENELITIAN}

Penelitian dilaksanakan di PT Perkebunan Tambi Wonosobo dan Laboratorium BPTP Yogyakarta. Perlakuan yang digunakan adalah kontrol (tanpa menggunakan EM-4) dan penggunaan EM-4 pada fermentasi limbah cair teh hijau. Fermentasi limbah cair teh hijau dilakukan dengan penambahan starter EM4 dengan dosis $10 \mathrm{ml}$ EM-4 per liter limbah cair dengan penambahan gula merah sebanyak 100 gr. Fermentasi dilakukan selama 14 hari dan pengukuran $\mathrm{pH}$, suhu, konsentrasi larutan, dilakukan di hari ke-14. Fumigasi dilakukan pada media bibit top soil dan sub soil menggunakan Dolomit, Basamid, Dhythane dan SP-36. Pada top soil penggunaan Dolomit: Basamid: Dhythane: Sp-36 dengan dosis 500 gr: 150 gr: 400 gr: 600 gr per $\mathrm{m}^{3}$ tanah. Untuk tanah sub soil fumigasi menggunakan Dolomit: Basamid: Dhythane dengan dosis 225 gr: 37,5 gr: 75 gr per $\mathrm{m}^{3}$ tanah. Semua bahan dicampurkan dengan tanah kemudian setelah tercampur rata media ditutup rapat menggunakan plastik selama 2 minggu (14 hari). Media disiram menggunakan air sampai dengan kapasitas lapang, ditunggu kurang lebih 60 menit kemudian diaplikasikan hasil fermentasi limbah cair teh hijau sesuai perlakuan dengan cara disiramkan ke media tanam. Kemudian media diistirahatkan selama 24 jam sebelum ditanami. Stekres/bahan stek diambil dari kebon entrees yang ada di Kebun Tanjungsari. Bahan stek yang digunakan adalah Klon Gambung 7. Stekres dipotong dengan ketentuan 1 stekres memiliki 1 mata tunas aktif dan satu daun, diambil bagian batang berwarna coklat muda sampai hijau tua atau sekitar 4 sampai 7 daun setelah peko. Setelah itu, stekres dicupir/dipotong daunnya sebagian kemudian dimasukkan dalam ember yang berisi larutan Dhytane dan Rooton-F konsentrasi 0,025\% direndam selama kurang lebih 2 menit. Penanaman stekres beriringan/sehadap atau tidak boleh bolak-balik. Kemudian penyungkupan dilakukan selama 2 bulan tanpa dibuka. Pengamatan dilakukan 2 bulan setelah aplikasi pertama terhadap prosentase bibit tumbuh dan setelah aplikasi ke-2 diamati setiap bulan terhadap tinggi tanaman, jumlah daun serta kehijauan daun. Analisis data dilakukan dengan uji $\mathrm{t}$ ( $t$-test) terhadap data variabel pertumbuhan pada tingkat signifikansi $95 \%$.

\section{HASIL DAN PEMBAHASAN}

Pemberian hasil fermentasi limbah cair teh hijau belum memberikan pengaruh nyata pada persentase bibit tumbuh, pertumbuhan tinggi tanaman, jumlah dan kehijauan daun. Hal ini dikarenakan beberapa faktor antara lain kondisi lingkungan (jenis tanah di UP Tanjungsari), aplikasi hasil fermentasi yang dilakukan dua kali (pada awal penanaman dan buka sungkup) dan kandungan hara yang ada dalam limbah cair teh hijau yang rendah. 
Tabel 1. Persentase Bibit Tumbuh, Tinggi Tanaman, Jumlah dan Kehijauan Daun

\begin{tabular}{lcccc}
\hline \multicolumn{1}{c}{ Perlakuan } & $\begin{array}{c}\text { Persentase Bibit } \\
\text { Tumbuh }\end{array}$ & Tinggi Tanaman & $\begin{array}{c}\text { Jumlah } \\
\text { Daun }\end{array}$ & $\begin{array}{c}\text { Kehijauan } \\
\text { Daun }\end{array}$ \\
\hline $\begin{array}{l}\text { Tanpa Limbah } \\
\text { Cair Teh }\end{array}$ & $0.77 \mathrm{a}$ & $10.50 \mathrm{a}$ & $3.23 \mathrm{a}$ & $1.50 \mathrm{a}$ \\
$\begin{array}{l}\text { Penggunaan } \\
\text { Limbah Cair } \\
\text { Teh }\end{array}$ & $0.81 \mathrm{a}$ & $11.69 \mathrm{a}$ & $3.92 \mathrm{a}$ & $1.65 \mathrm{a}$ \\
\hline \multicolumn{1}{c}{-test 5\% } & 0.23 & 3.89 & 1.37 & 0.48 \\
\hline
\end{tabular}

Keterangan : Angka yang diikuti huruf yang sama pada kolom yang sama tidak berbeda nyata pada uji $\mathrm{t}(\mathrm{t}$-test) taraf $5 \%$

Pada persentase bibit tumbuh, aplikasi hasil fermentasi limbah cair teh hijau dan tanpa pemberian limbah cair teh hijau tidak menunjukkan perbedaan nyata. Pada persentase bibit tumbuh menunjukkan bahwa persentase bibit hidup $81 \%$ (fermentasi limbah cair teh hijau) dan $77 \%$ (limbah teh hijau tanpa fermentasi), seiring berjalannya waktu ada beberapa bibit yang tumbuh abnormal atau mati. Pertumbuhan abnormal bibit ditandai dengan terbentuknya gall atau kalus di ujung stek yang tertanam di media tanam dan akar tidak tumbuh. Hal ini menjadi salah satu indikator bibit tumbuh kerdil, tunas/pucuk tidak tumbuh bahkan bibit mengalami kematian. Pertumbuhan kalus pada bibit juga menunjukkan kemungkinan bibit terserang oleh nematoda. Kebersihan dan sterilitas stekres dan media menjadi salah satu faktor yang menentukan pertumbuhan bibit secara sempurna dan hasil fermentasi limbah cair teh hijau menggunakan mikroorganisme belum menunjukkan kemampuannya untuk menghasilkan hormon tumbuh dan antiseptik bagi media tanam bibit teh. Husen et.al., (2006), menyatakan bahwa peran mikroorganisme untuk penambat unsur hara atau pun penghasil hormon pertumbuhan, menekan penyakit yang ditularkan melalui tanah dan melarutkan hara tidak tersedia menjadi tersedia.
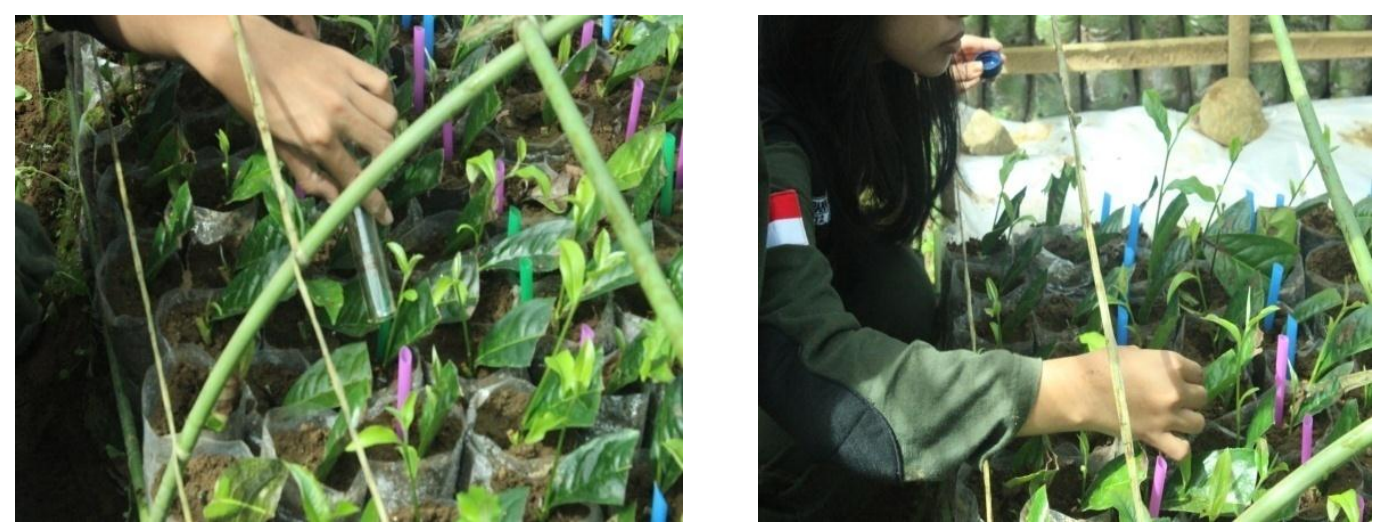

Gambar 1. Aplikasi Limbah Cair Dan Pengamatan Pertumbuhan Bibit

Jenis tanah di UP Tanjungsari adalah tanah Latosol, merupakan jenis tanah serasi bersyarat bagi tanaman teh yang membutuhkan syarat dan perlakuan khusus jika digunakan sebagai media tanam teh. Berdasarkan hasil analisis tanah tahun 2015 menunjukkan bahwa tanah di UP Tanjungsari memiliki kandungan C- 
organik 2,69 (sedang), $\mathrm{N}$-total 0,30 (sedang), $\mathrm{C} / \mathrm{N}$ ratio 8,97 (rendah), $\mathrm{P}_{2} \mathrm{O}_{5} 145$ (tinggi) dan $\mathrm{K}_{2} \mathrm{O}_{5}$ (rendah) (Laboratorium BPTP Yogyakarta (2015) dalam Muningsih dan Susilowardani, 2015). Salah satu faktor pembatas yang dihadapi pada saat penelitian adalah jenis tanah, $\mathrm{N}$ total dan kandungan bahan organik tanah. Kedua faktor pembatas ini masuk dalam kategori I (struktur tanah) dan kategori III (kadar $\mathrm{N}$ total dan C-organik pada tanah top soil) (Arifin, et.,al., 1992). Jenis tanah yang digunakan sebagai media tanam merupakan tanah serasi bersyarat bagi tanaman teh, yaitu jenis tanah Latosol. Tanah serasi bersyarat untuk tanaman teh adalah tanah yang memiliki kedalaman efektif dan berstruktur remah/gumpal lemah minimal $40 \mathrm{~cm}$. Tanah Latosol adalah tanah yang memiliki sifat: warna tanah sekitar merah, tekstur lempung sampai geluh, struktur remah sampai gumpal lemah, menjadi lengket saat terkena hujan dan keras ketika kekeringan, $\mathrm{pH}$ tanah rendah dan tersebar di daerah dengan curah hujan tinggi dari ketinggian $0 \mathrm{~m}$ dpl sampai $900 \mathrm{~m}$ dpl (Arifin, et., al., 1992). Kadar N total dan Corganik yang rendah menyebabkan kadar $\mathrm{C} / \mathrm{N}$ ratio rendah. $\mathrm{C}$-organik merupakan sumber hara dan energi bagi kehidupan organisme heterotrof tanah. Kandungan C-organik rendah bisa menjadi faktor pembatas pada keberadaan organisme tanah.

Tanah Latosol pada umumnya bertekstur liat, kurang gembur, dan memiliki Kapasitas Tukar Kation (KTK) rendah. KTK berkaitan dengan mudah tidaknya penyerapan unsur hara bagi tanaman. Tekstur liat pada tanah latosol menyebabkan tanah Latosol menjadi sangat liat jika terkena air dan jika kekeringan menjadi pecah-pecah. Kondisi tanah yang lembab dan basah menyebabkan nematoda mudah menyerang. Diketahui bahwa pada umumnya nematoda seringkali ditemukan di bagian akar, terutama di bagian rhizosfer akar. Serangan nematoda ini ditandai dengan munculnya gall (puru) pada akar (rootknot nematoda), perubahan warna akar menjadi kekuningan atau coklat, terbentuknya akar cabang yang tidak normal dan terjadinya akar cabang yang pendek. Akar cabang yang pendek seringkali terjadi karena adanya terhentinya pertumbuhan akar cabang ke samping (coarse root). Akibat serangan nematoda puru akar juga menyebabkan daun gugur, bibit gundul, hanya tinggal daun di pucuk. Hal ini seringkali menyebabkan bibit mengalami pertumbuhan yang lebih lambat.

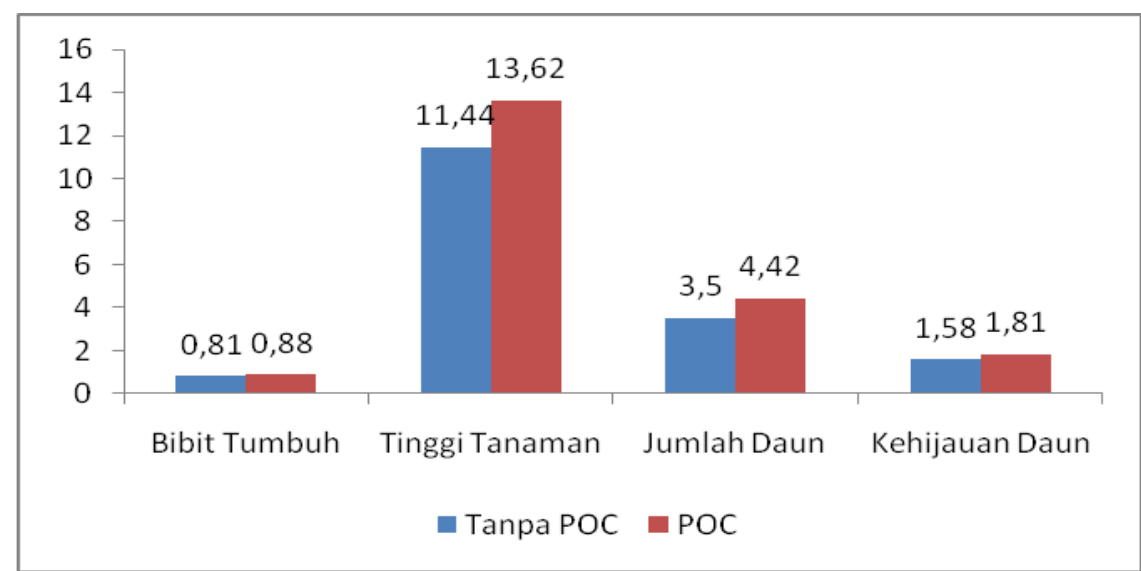

Gambar 1. Persentase Bibit Tumbuh Dan Pertumbuhan Bibit Teh 
Aplikasi fermentasi limbah cair teh hijau yang hanya dilakukan dua kali diduga menyebabkan efek/pengaruh yang timbul kurang terlihat. Berdasarkan anjuran EM-4 penggunaan hasil fermentasi dengan memanfaatkan EM-4 pada bibit tanaman perkebunan dilakukan seminggu sekali dengan takaran $10 \mathrm{ml}$ per tanaman. Pemanfatan organisme pendegradasi bahan organik membutuhkan kondisi lingkungan dan bahan yang berbeda-beda. Apabila kondisinya sesuai, maka dekomposer tersebut akan bekerja giat untuk mendekomposisi limbah organik. Apabila kondisinya kurang sesuai atau tidak sesuai, maka organisme tersebut akan dorman, pindah ke tempat lain, atau bahkan mati. Menciptakan kondisi yang optimum untuk proses pengomposan sangat menentukan keberhasilan proses pengomposan itu sendiri. Pada umumnya di lingkungan perkebunan sudah terdapat mikroorganisme, hanya saja karena kurangnya bahan organik (di bawah 2\%) dapat menyebabkan populasi mikroorganisme menjadi sangat sedikit sehingga tidak bisa memberikan nutrisi dan berbagai senyawa bermanfaat bagi tanaman.

Hasil pengamatan pada $\mathrm{pH}$, suhu dan konsentrasi larutan selama fermentasi adalah $\mathrm{pH}$ antara 4.5-4.7, suhu rata-rata $27-29^{\circ} \mathrm{C}$ dan konsentrasi larutan antara 2.710-2.810 ppm. Pada proses fermentasi suhu/temperatur dan $\mathrm{pH}$ menjadi salah satu tolak ukur keberhasilan hasil fermentasi. Ada hubungan langsung antara peningkatan suhu dengan konsumsi oksigen oleh mikroorganisme pada saat proses fermentasi. Semakin tinggi temperatur akan semakin banyak konsumsi oksigen dan akan semakin cepat pula proses dekomposisi. Peningkatan suhu berkisar antara $30-60^{\circ} \mathrm{C}$ menunjukkan aktivitas dekomposisi yang cepat. Suhu yang lebih tinggi dari $60^{\circ} \mathrm{C}$ akan membunuh sebagian mikroba dan hanya mikroba thermofilik saja yang akan tetap bertahan hidup.

Sementara itu, pada proses fermentasi dapat terjadi pada kisaran $\mathrm{pH}$ antara 6.5 sampai 7.5. Proses fermentasi akan menyebabkan perubahan pada bahan organik dan $\mathrm{pH}$ bahan itu sendiri, misalnya proses pelepasan asam, secara temporer atau lokal, akan menyebabkan penurunan $\mathrm{pH}$ (pengasaman), sedangkan produksi amonia dari senyawa-senyawa yang mengandung nitrogen akan meningkatkan $\mathrm{pH}$ pada fase-fase awal fermentasi. $\mathrm{pH}$ kompos yang sudah matang biasanya mendekati netral. Djuarnani (2005), berpendapat bahwa derajat kemasaman bahan pada permulaan pengomposan umumnya asam sampai dengan netral yakni antara 6,0-7,0. Derajat kemasaman perlu dikontrol selama proses fermentasi berlangsung. Jika derajat kemasaman terlalu tinggi atau terlalu basa, konsumsi oksigen akan naik dan akan memberikan hasil yang buruk bagi lingkungan. Derajat kemasaman yang terlalu tinggi juga akan menyebabkan unsur nitrogen dalam bahan yang difermentasi berubah menjadi amonia (NH3). Sebaliknya, apabila derajat kemasaman rendah (asam) akan menyebabkan sebagian mikroorganisme mati.

Limbah yang terfermentasi menjadi kompos akan bisa dimanfaatkan setelah mengalami fermentasi satu bulan. Waktu fermentasi yang kurang dari satu bulan bisa jadi menyebabkan limbah cair teh hijau memiliki kadar N, P, K dan unsur mikro lain rendah. Pada penelitian yang dilakukan Cesaria et. al, menyebutkan bahwa fermentasi limbah cair tahu dapat aplikasikan setelah 30 hari 
setelah fermenentasi, sedangkan Wulandari dan Riska (2010), menyimpulkan bahwa untuk mengolah air limbah tahu membutuhkan 84 hari.

Pemanfatan organisme pendegradasi bahan organik membutuhkan kondisi lingkungan dan bahan yang berbeda-beda. Apabila kondisinya sesuai, maka dekomposer tersebut akan bekerja giat untuk mendekomposisi limbah organik. Apabila kondisinya kurang sesuai atau tidak sesuai, maka organisme tersebut akan dorman, pindah ke tempat lain, atau bahkan mati. Organisme pendegradasi bahan organik membutuhkan kondisi lingkungan dan bahan yang berbeda-beda. Apabila kondisinya sesuai, maka dekomposer tersebut akan bekerja giat untuk mendekomposisi limbah organik. Apabila kondisinya kurang sesuai atau tidak sesuai, maka organisme tersebut akan dorman, pindah ke tempat lain, atau bahkan mati. Menciptakan kondisi yang optimum untuk proses pengomposan sangat menentukan keberhasilan proses pengomposan itu sendiri.

\section{KESIMPULAN}

Pemanfaatan limbah cair teh hijau dengan penambahan starter (EM-4) belum menunjukkan pengaruh nyata terhadap persentase bibit tumbuh dan pertumbuhan bibit (tinggi tanaman, jumlah dan kehijauan daun), meskipun ada tren pertumbuhan yang meningkat pada penggunaan limbah cair teh hijau yang difermentasi.

\section{DAFTAR PUSTAKA}

Anonym, 2006. Peraturan Menteri Pertanian No. 2/Pert/HK.060/2/2006.

Arifin, Sultoni. M., Sanusi, M., Sugeng A., Atik D., M. Isa Dharmawijaya, Martanto M., Warli S K., Astika, W., M. Thobroni, Suharlan T., Edi S., Zuhdi S W., Buang S., Muchsin S, 1992. Petunjuk Kultur Teknis Tanaman Teh. Asosiasi Peneliti dan Pengembangan Perkebunan Indonesia, PPTK Gambung, Bandung.

Djuarnani, N., Kristian dan Budi S.S. 2005. Cara Cepat Membuat Kompos. Agromedia Pustaka. Jakarta

Donahue, R. L,W. 1970. Soils an Introduction to Soil and Plant Growth. Prentice hall, inc. New Jersey.

Husen, R., R. Stakaranwati dan R. D. Hastuti, 2006. Rhizobakteri Pemacu Tumbuh Tanaman. Dalam Pupuk Organik dan Pupuk Hayati. Balai Penelitian Tanah. P. 191-209.

Irlbeck, N.A. 2000. Basic of Alpaca Nutrition. Alpaca Owners and Breeder Association Annual Conference Procedings. June 4. Louisville.

Muningsih, Retno dan Susilawardani, 2015. Pengaruh Penggunaan Biofertilizer Untuk Meningkatkan Kesehatan Tanaman Dan Pemecahan Pucuk 
Dorman Pada Bibit Teh Di PT Tambi. Laporan Penelitian Penelitian Dosen Pemula, Kementerian Riset dan Teknologi, Indonesia.

Panuju, Tunggul Dimas, 2007. Teh dan Pengolahannya. Data diakses 17 Agustus 2011 pukul 11.05 am.

Retnowati, 2005. Efektivitas Ampas Teh Sebagai Adsorben Alternatif Limbah Cair Industri Tekstil. Skripsi. Departemen Kimia, Fakultas Matematika dan Ilmu Pengetahuan Alam, Institut Pertanian Bogor, Bogor

Triharso, 1994. Dasar-dasar Perlindungan Tanaman. Gadjah Mada University Press. Yogyakarta.

Wulandari Desi dan Riska Hesti Marlitasari, 2010. Proses Pengolahan Limbah Cair Domestik Secara Anaerob. Jurusan Teknik Kimia, Fakultas Teknik. Universitas Diponegoro, Semarang.

Yuli A. Hidayati.et al. 2011. Kualitas pupuk cair hasil pengolahan Feses Sapi Potong Menggunakan Saccharomyces cereviceae. Jurnal Ilmu Ternak Vol.11, No.2.

Yuniwati, Murni, Frendi Iskarina dan Adiningsih Padulembe, 2012. Optimasi Kondisi Proses Pembuatan Kompos Dari Sampah Organik Dengan Cara Fementasi Menggunakan EM4. Jurnal Teknologi vol. 5 No. 2 Desember, IST AKPRIND, Yogyakarta. p. 172 \pm 181 . 